Fox. He was like Van Buren, cunning and polite. So that he was well provided for, he gave himself little care for his people. He was unpopular with his nation; had never but a small band about him. It was only that the United States Government, in its sovereign power, recognized him ehief, that he was enabled to exercise any influence-less influence than when he was the orator, because the other chiefs and the people thought injustice had been done them.

Keokuk was a dissolute man and a drunkard. He always had a plurality of wives.

I only speak of Keokuk from personal knowledge. I knew him intimately. He often ate at my table with my self and family, as did the other chiefs.

I have a word to say for Black Hawk. He was one of the most abused man and the most honest man I ever knew. He was loyal to his people-he loved them, and was by them beloved. He had a fine family, never but one wife. He died a broken-hearted man. I should add that Keokuk was a stout-built man - I should judge that he weighed from one hundred and eighty to two hundred pounds, and that he was about five feet eight inches tall.

I have been here twenty-eight years. Time does indeed fly.

D. W. Kilbourne.

\title{
REMARKS OF REV. SAMUEL STORRS HOWE,
}

AT THE YOUNG MEN'S CHRISTIAN ASSOCIATION, IN NOVEMBER, 1868 - NOW A MATTER OF HISTORY.

The public meeting of the Young Men's Christian Association of Iowa, being thrown open for remarks, by the President, with the request that any on€ would make encouraging suggestions, Mr. Howe arose and said:

I do not know, Mr. President, but I ought to apologize for rising to speak first; yet, as the minister longest resident in town, present at this meeting, I will venture a few remarks.

It is no child's play to do Christian work in Iowa City. It is the hardest field I ever wrought in. I do not know as to the new-comers in this city; but the old settlers are like the rocks in our quarries, that have to be blasted out.

Indeed, this, like every other place, has its type, as disease has in 
any country. For example, some years ago a physician came to this country from Pennsylvania, where typhoid fever was common, and everybody in his practice had the typhoid fever, while old physicians found only severe bilious fever cases, and no well-defined instance of typhoid fever. It is important, therefore, to study the type of depravity among us, in order to do Christian duty.

It has been said, that God made the country and man made the city. I do not think that God had much to do with making Iowa City. The capital of the State was held here, at one time, by keeping one member of the Legislature drunk at a certain hotel (pointing in that direction).

'The State House was built by the General Government and the State Government. The churches were mostly built by aid from abroad. The State University, finally located here instead of the capitol buildings, is endowed by the National and State Governments. A few public-spirited citizens only gave five thousand dollars, I believe, to secure a legislative endowment or to supplement it. Iowa City, heretofore, has always been helped in these respects. But the time is come when we must do our own work,-especially our own Christian work. Begging for building churches in Iowa City, from abroad, is played out. We must now do own evangelical work ourselves, be it ever so hard work.

Again, the diversity of languages here makes it hard work to do good to all men. You will have to employ other tongues than we speak, or than are taught in our University, to find access to a considerable portion of our people,- the Bohemian language in particular, I mention, as I have been among this class somewhat, and am soon to take up my abode among them. I have found Bohemians honest and intelligent. Down in the other end of town, where I have lived, my saw-horse and my wood-saw were stolen! But up among the Bohemians, I have not lost a thing, not even the chips and boards lying around loosely. While, down in town, mechanics tell me they can leave nothing outdoors; and a police watchman would be needed night and day, to prevent things being carried off.

Besides, they are intelligent people. One man, pursuing a humble employment in our city, has imported from his native land of Bohemia a work on Natural History, duties paid, costing one hundred dollars. And another, a grandfather among them, when asked whether he was a Catholic or a Protestant, replied, in broken English, "a Christian!"

It was in Bohemia, in reality, that the Reformation began, before Luther's day, under John Huss. And, during the last year, a grand procession and visitation, in honor of his martyrdom, to the spot where he suffered, took place in that country.

Were $I$ as young as some of the young men of your Association, I would learn Bohemian (as I do some words almost every day) and seek access to this people in their own language. To be sure, you can approach them through their children, who learn and speak English. Let, then, some of the young men and young women overcome this difficulty 
by learning Bohemian, and so become missionaries at home in this city, or go as missionaries to the land of John Huss, the first reformer.

One word more,- -some young people act as if they thought modesty were not a virtue. Let such read the discourse of Dr. Chalmers, on the modesty of science, and learn what a grace modesty is in learning to do good. Modesty and piety, my young friends, will carry you anywhere in your work of well-doing. And may God give you these graces, and success in all your benevolent undertakings.

Iowa City, Jan. 6, 1869.

\section{ORIGIN AND SIGNIFICATION OF THE NAME DES MOINES.}

The following correspondence as to the name of Des Moines, is given with respect to the various views which are entertained:

DaVENPORT, March 11, 1858.

Rev. S. Storrs Howe: - I hunted up my old friend, "Father" Pelemarques, who informs me the correct writing of the river is Des Moines -meaning "of the Monks;" that is, the River of Monks. He says he once met an old Frenchman, who had seen the remains or ruins of the convent. . . The river, therefore, was the River Des Moines, or "River of the Monks."

Yours truly,

H. Y. Slaymaker.

Reo. S. S. Honoe, Des Moines, Ioroa,-

DAVENPoRT, March 11, 1858.

Dear Sir:- I received your note this morning, in regard to the definition of "Des Moines." The name was given by the Indians; that is, the Indians living this side of the river were a large tribe, and those on the other side were few in number, and had there the name of Des Moines, meaning the small tribe of Indians. As regards some persons saying it was derived from the Monks, that is incorrect.

Respectfully yours,

Antoine LeClatre.

Of course, the editor and the public must concede to $\mathrm{Mr}$. Le Claire the true explanation and signification to be "De Moins," or "De Moine," that is "the less" tribe, and so transferred to the river, and from it to the city of De Moin, as it may well be spelled, leaving off the hissing letter " $s$," as the French do not sound it. 
Copyright of Annals of Iowa is the property of State of Iowa, by \& through the State Historical Society of Iowa and its content may not be copied or emailed to multiple sites or posted to a listserv without the copyright holder's express written permission. However, users may print, download, or email articles for individual use. 